\title{
Determinants of Dividend Payout Ratio in Non-Financial Companies Listed
}

\author{
Wafa Anggraeny ${ }^{1}$, Robiyanto Robiyanto ${ }^{2 *}$, Imanuel Madea Sakti ${ }^{3}$ \\ 1,2,3Universitas Kristen Satya Wacana, Salatiga, Indonesia
}

\section{A R T I C L E I N F O}

Article history:

Received 10 September 2020

Received in revised form

15 October 2020

Accepted 26 October 2020

Available online 01

November 2020

Keywords:

Dividend Payout Ratio, Firm Size

\begin{abstract}
A B S T R A C T
This study aims to analyze the effect of both internal and external factors that determine the dividend payout ratio of non-financial companies listed in the IDX High dividend 20 during the period of 2015-2019. The independent variables of the company's internal factors are return on assets, earnings per share, and debt to equity ratio. The independent variables of the company's external factors are interest rates and inflation. The control variable used in this study is firm size. There were 13 companies listed in IDX High Dividend 20 by using the purposive sampling method. Data analysis used panel data regression which was analyzed three times by grouping the dividend payout ratio, low dividend, and high dividend. The results showed that the return on assets had a significant negative effect on the combined dividend payout ratio with a probability value $(0.0309)$ and high dividend with a probability value $(0.0067)$ smaller than the significance level $(5 \%)$, but had no significant effect on the low dividend with a probability value $(0.3283)$
\end{abstract} greater than the significance level (5\%). Earnings per share has no significant effect on the combined dividend payout ratio with a probability value $(0.4151)$, low dividend with a probability value $(0.1164)$, and high dividend with a probability value $(0.3835)$ greater than the significance level $(5 \%)$. It can be concluded that return on assets earning per share, firm size, and debt to equity ratio have an effect on dividend payout ratio.

Copyright (C) Universitas Pendidikan Ganesha. All rights reserved.

\section{Introduction}

Economic Economy has a vital role in Indonesia and the development of the economy in this country can be measured based on the level of development of the capital market investment. The capital market provides a place and facilities to meet parties who need funds (issuer) with those who provide funds (investors). This is an opportunity for investors to increase their assets because the capital market provides a relatively high rate of return. In investment, investors or shareholders expect dividends and capital gains as the rate of return on their investment with the needs and objectives of the investor as the basis for the return (Lucyanda \& Lilyana, 2012; Tandelilin, 2010). The clientele effect theory and bird in hand theory explains that dividends are seen more certain than capital gains if investors choose dividends as their investment priority. But what distinguishes these two theories is that the clientele effect is divided of a group of shareholders who expect dividends with a high dividend payout ratio depending on the required income, while in the bird in hand theory, shareholders assumes that the increase in the cost of company capital is due to dividend payout ratio shared low (Al-Malkawi et al., 2010; Keown et al., 2003). The dividend expected by shareholders is able to provide growth rate as well as a dividend distribution rate in accordance with the company's profits.

The dividend is a distribution of profit to shareholders from the number of shares owned. In its distribution, the company has choices to distribute dividends or save company profits as an investment in business development. By distributing dividends, the company's profit will decrease, but, if it is not distributed to shareholders, it can increase internal sources of funding resulting in a decrease in the welfare of shareholders. In general, shareholders expect a relatively stable dividend distribution (Okpara, 2010; Zulkifli et al., 2017). Dividends can be said optimal if current dividends are able to balance with the future dividend growth so that the company will get the maximum share price (Brigham and Houston 2011, 198). Dividend policy can be measured by the cash dividend percentage of profits distributed to shareholders, it's called the Dividend Payout Ratio (DPR). The higher the value of the company's dividend

*Corresponding author.

E-mail address: robiyanto.robiyanto@uksw.edu 
payout ratio (DPR), the higher the number of dividends that will be distributed to shareholders, and it affects the increase of the share price, but the company's internal funding weakens because retained profits get lower. On the other hand, the lower the value of the company's DPR, the lower the amount of dividends that will be distributed and it is detrimental to shareholders, but the company's internal funding gets higher (Harianja, et al., 2013; Purwanti \& Sawitri, 2011; Yudea, 2017).

Based on the company's dividend policy, the Indonesia Stock Exchange in May 2018 announce officially a new stock index, namely the IDX High Dividend 20. The IDX High Dividend 20 consists of 20 shares of companies listed on the IDX which have routinely distributed cash dividends in the past 3 years and have high dividend yield (yield) to shareholders. The IDX High Dividend 20 index performance every 6 months in early February and August will constantly be monitored Indonesia Stock Exchange, if shares in this index are declared unfit after evaluation, these shares will be replaced by other stocks that meet predetermined criteria (www. idx.co.id). According to the launch of the IDX High Dividend 20 stock index, there is still not much literature discussing about that index.

The decrease in the dividend payout ratio was also caused by the decrease in the average net profit in 2019 of the IDX High Dividend 20 registered company, which shows that the company's management performance is closely related to considering the value of the DPR, because by having a good financial performance the company is expected to be able to determine the amount of the dividend payout ratio which are distributed according to the expectations of shareholders (Rahayuningtyas, Suhadak, and Handayani, 2012). Financial performance can also be interpreted as an internal factor in determining the value of the DPR.

Return on assets (ROA) as a proxy to measure the company's profitability and ability to pay the dividend. Profitability analysis is crucial for shareholders to see the profit received in the form of dividends on long-term investments. The higher the increase of the ROA value, the better the company's performance, and it increases the dividend revenue (Ardiyanti, 2014; Zulkifli et al., 2017). Previous researches conducted by (Amah, 2012; Sunarya, 2013; Zulkifli et al., 2017) explained that ROA affects the DPR in a positive way. Otherwise, researches by (Atmoko et al., 2017; Hasan et al., 2015) explained that the DPR is negatively affected by ROA.

Earnings per share (EPS) is the distribution of net income by the company to all shareholders. A high EPS means that the company has reached the peak of success and it indicates that the company distributes dividends in the form of outstanding shares and has a high ability to pay dividends (Ardiyanti, 2014; Zulkifli et al., 2017). Previous research by (Saeed et al., 2014; Zulkifli et al., 2017) obtained EPS results positively affecting the DPR. Conversely, research by (Hasan et al., 2015) found that the DPR results were negatively affected by EPS.

The debt to equity ratio (DER) is the ratio of the company's total debt to its capital. The high use of loans indicates that the company's obligation to pay the loan will be the company's top priority rather than dividend distribution (Laim et al., 2015; Mufidah, 2018). Researches by (Amah, 2012; Atmoko et al., 2017; Odawo \& Ntoiti, 2015) explained that the DPR is positively influenced by DER. On the other hand, researches by (Laim et al., 2015; Zulkifli et al., 2017) explained that DER affects the DPR negatively.

Besides internal factors in financial performance in determining the amount of the DPR, there are also external factors, including interest rates and inflation. Most of the other studies only focus on internal factors of financial performance because they are closely related in determining the amount of the dividend payout ratio, whereas investing in the capital market not only provides results but also there are risks caused by the economic, social and political conditions of a country so that interest rates and inflation is also a variable that dominantly affects dividends. Inflation increases company revenues and costs. If the increase in production costs is higher than the feasible price, it can decline the profitability resulting in a reduction of dividends paid to shareholders. A high-interest rate also indicates high investment risks and it makes shareholders want high returns (Ardiyanti, 2014; Tandelilin, 2010).

Firm size is added to this study as the control variable. Firm size is the size of a company. Large companies have a higher operating cash flow so that the dividend paid is high (Silaban \& Pengestuti, 2017). Previous researches by (Atmoko et al., 2017), (Febriani \& Sari, 2019) firm size has a significant positive effect on the DPR. Conversely, research by (Aziza et al., 2020) explained firm size has no effect on the DPR.

In this study, the DPR is classified into companies that have high dividend and low dividend by looking at the value of the company's DPR compared to the average of the overall DPR. DPR with a higher value than the overall average will be classified as high dividend and DPR with a lower value than the overall average will be classified as low dividend. The grouping uses to compare the two dividend groups and see the difference effect between variables.

This study aims to analyze the effect of return on assets, earnings per share, debt to equity ratio, interest rates, inflation, and firm size on the dividend payout ratio and to contribute to the literature 
review about dividend policy which is influenced by financial performance, interest rates, and inflation. This research expected to be able to provide benefits to investors in providing information and recommendations as a basis for making investment decisions that financial performance, interest rates, and inflation are also the factors that influence dividend policy

\section{Methods}

The type of data used in this study is quantitative data with secondary data sources. Secondary data is obtained from the annual financial statements of companies listed in the IDX High Dividend 20 index for the 2015-2019 period through the Indonesia Stock Exchange website (idx.co.id), inflation data and also the BI 7-Day Repo Rate obtained from the website of the Indonesian Central Bureau of Statistics (bps.go.id). The population and research sample are companies listed in the IDX High Dividend 20 stock index which there are 20 listed stocks, but not all 20 listed stocks will be selected as samples in the study. The sample will be determined through purposive sampling technique.

The data analysis technique used is panel data regression, which is a regression technique that combines time series and cross section data. Software Eviews 10 is used as a research data processing tool. The first step of the test is to determine the appropriate estimation model in the form of the Common Effect Model (CEM), Fixed Effect Model (FEM), and Random Effect Model (REM) methods. CEM uses a Pooled Least Square approach which only combines time series and cross section data which in several time periods assumed the same data-behaviors of the company. FEM uses the Least Square Dummy Variable (LSDV) approach which obtain constant regression coefficients for each company and each time, so that the differences between companies can be seen from the differences in the intercept. REM uses the Error Component Model approach or the Generalized Least square technique by providing additional variables that may appear in each company and at times in the form of variable error terms. Estimation model selection is done by using the Chow test to determine the most appropriate model between FEM and CEM. The Hausman test is used if the Chow test obtains the FEM estimation model. So, the Hausman test is performed to choose an estimation model between FEM and REM. Lagrange Multiple Test is used if the Chow test gets the CEM estimation results and the Hausman test gets the REM estimation results so that an appropriate estimate of the two results is chosen. And then, the normality test uses to determine the dependent and independent variables in a regression model with a normal distribution. Multicollinearity test to determine if there is a relation between two or more independent variables. Heteroscedasticity test to see if there are differences in the variance of observations between each residual.

\section{Results and Discussions}

Descriptive statistics result in Table 1 show that the dependent variable used by the DPR has a mean value of $62.07387 \%$, standard deviation of $34.47749 \%$, a maximum value of $176.68 \%$ and a minimum value of $10.66 \%$. The independent variable ROA has a mean value of $16.1921 \%$, a standard deviation of $11.29619 \%$, a maximum value of $46.3 \%$ and a minimum value of $4 \%$. EPS has a mean value of 765.1613 rupiah per share, a standard deviation of 1006.496 rupiah per share, a maximum value of 4050 rupiah per share and a minimum value of 43 rupiah per share. DER has mean value 0.892742 times, standard deviation 0.682282 times, maximum value 2.91 times and minimum value 0.15 times.

Table 1. Descriptive Statistics

\begin{tabular}{ccccccc}
\hline Variable & Obs. & Maximum & Minimum & Mean & Std. Dev & Unit \\
\hline DPR Combined & 65 & 176.68 & 10.66 & 62.07387 & 34.47749 & Percent $(\%)$ \\
ROA & 65 & 46.300 & 4.000 & 16.19210 & 11.29619 & Percent (\%) \\
EPS & 65 & 4050.0 & 43.00 & 765.1613 & 1006.496 & Rupiah per share \\
DER & 65 & 2.9100 & 0.150 & 0.892742 & 0.682282 & Times \\
INTEREST RATE & 65 & 7.5200 & 4.560 & 5.737903 & 1.011884 & Percent $(\%)$ \\
INFLATION & 65 & 3.6100 & 2.720 & 3.177419 & 0.298713 & Percent (\%) \\
FIRM SIZE & 65 & 19.6800 & 15.17 & 17.53597 & 1.076106 & Percent (\%) \\
\hline
\end{tabular}

The interest rate has a mean value of $5.737903 \%$, a standard deviation of $1.011884 \%$, a maximum value of $7.52 \%$ and a minimum value of $4.56 \%$. Inflation has a mean value of $3.177419 \%$, a standard deviation of $0.298713 \%$, a maximum value of $3.61 \%$ and a minimum value of $2.72 \%$. Firm size has a mean value of $17.53597 \%$, standard deviation of $1.076106 \%$, a maximum value of $19.68 \%$ and a minimum value 
of $15.17 \%$. It can be concluded that the standard deviation value of EPS is greater than the mean value, while the standard deviation of DPR, ROA, DER, Interest Rate, Inflation, and Firm Size is smaller than the mean value which indicates that these variable data can use as good represent data for this research.

\section{Determination of Panel Regression Estimation Model}

The regression estimation model was selected by using panel regression test. The estimation results of the panel regression model can be seen in Table 2.

Table 2. Panel Regression Model Estimation Results

\begin{tabular}{llcccccc}
\hline & & \multicolumn{2}{c}{ Chow Test } & \multicolumn{2}{c}{ Hausman Test } & \multicolumn{2}{c}{ LM Test } \\
\cline { 3 - 8 } & & $\begin{array}{c}\text { Chi Square } \\
\text { Prob. }\end{array}$ & Result & $\begin{array}{c}\text { Cross-section } \\
\text { Random Prob. }\end{array}$ & Result & $\begin{array}{c}\text { Breusch- } \\
\text { Pagan Prob. }\end{array}$ & Result \\
\hline$[1]$ & DPR Combined & 0.0000 & FEM & 0.0888 & REM & 0.0000 & REM \\
{$[2]$} & Low Dividend & 0.0134 & FEM & 0.4531 & REM & 0.3355 & CEM \\
{$[3]$} & High Dividend & 0.0043 & FEM & 0.0245 & FEM & - & - \\
\hline
\end{tabular}

In Table 2, according to the determination of the estimation model, the first test uses the REM estimation model, the second test uses CEM, and the third test uses FEM.

\section{Normality Test}

The normality test is used to determine whether the research data is normally distributed or not. According to the data analysis, the normality test for each test obtains a probability value from the JarqueBera is greater than the $5 \%$ significance level. It can be concluded that the research data is normally distributed.

\section{Multicollinearity Test}

Multicollinearity test is used to see a correlation between two or more independent variables in the research data, it uses. If the VIF value is less than 10, it is said to pass the multicollinearity test. The multicollinearity test results can be seen in Table 3.

Table 3. Multicollinearity Test Result

\begin{tabular}{lccc}
\hline Independent Variable and & \multicolumn{3}{c}{ VIF } \\
\cline { 2 - 4 } \multicolumn{1}{c}{ Control Variable } & DPR Combined & Low Dividend & High Dividend \\
\hline ROA & 4.071 & 2.727 & 1.820 \\
EPS & 1.570 & 1.219 & 1.102 \\
DER & 6.875 & 1.911 & 1.860 \\
SUKU BUNGA & 1.777 & 1.031 & 1.093 \\
INFLASI & 1.376 & 1.033 & 1.097 \\
FIRM SIZE & 3.072 & 1.803 & 1.498 \\
\hline
\end{tabular}

In Table 3, it can be seen that the VIF value of all variables in the three tests has less than 10 , which means that the research data does not contain multicollinearity.

\section{Heteroscedasticity Test}

The heteroscedasticity test is used to see the residual variant inequality of the observations in the regression model. Based on data analysis, it can be seen that the chi-square probability value on the three tests obtained a value greater than the $5 \%$ significance level, so that the research data passed the heteroscedasticity test.

\section{Hypothesis Test}

Hypothesis test is performed by using panel data regression with unbalanced panel data on the low dividend and high dividend tests. Panel data regression test results can be seen in Table 4 . 
Table 4. Panel Data Regression Hypothesis Testing Results

\begin{tabular}{|c|c|c|c|c|c|}
\hline & Independent Variable & Coefficient & Std. Error & t-Statistic & Prob. \\
\hline [1] DPR & $\mathrm{C}$ & 37031.96 & 16160.73 & 2.291479 & 0.0258 \\
\hline \multirow[t]{6}{*}{ Combined } & ROA & -132.2238 & 59.67036 & -2.215904 & $0.0309 * *$ \\
\hline & EPS & -0.456612 & 0.556017 & -0.821219 & 0.4151 \\
\hline & DER & -472.3041 & 910.6371 & -0.518652 & 0.6061 \\
\hline & INTEREST RATE & -221.8953 & 259.9599 & -0.853575 & 0.3970 \\
\hline & INFLATION & 199.1192 & 870.2102 & 0.228817 & 0.8199 \\
\hline & FIRM SIZE & -15.56295 & 8.346123 & -1.864692 & $0.0676^{*}$ \\
\hline [2] Low & $\mathrm{C}$ & 3124.170 & 5098.842 & 0.612722 & 0.5452 \\
\hline \multirow[t]{6}{*}{ Dividend } & ROA & 31.23386 & 31.37276 & 0.995573 & 0.3283 \\
\hline & EPS & -0.454823 & 0.280406 & -1.622013 & 0.1164 \\
\hline & DER & -164.1023 & 354.9951 & -0.462266 & 0.6476 \\
\hline & INTEREST RATE & 6.551491 & 187.4282 & 0.034955 & 0.9724 \\
\hline & INFLATION & 894.0544 & 622.7793 & 1.435588 & 0.1626 \\
\hline & FIRM SIZE & -1.226451 & 2.468355 & -0.496870 & 0.6233 \\
\hline [3] High & $\mathrm{C}$ & 176908.9 & 120265.0 & 1.470992 & 0.1620 \\
\hline \multirow[t]{6}{*}{ Dividend } & ROA & -289.9570 & 92.19489 & -3.145044 & $0.0067^{* *}$ \\
\hline & EPS & -0.916849 & 1.021231 & -0.897788 & 0.3835 \\
\hline & DER & 1627.174 & 2608.839 & 0.623716 & 0.5422 \\
\hline & INTEREST RATE & -325.0832 & 645.4881 & -0.503624 & 0.6218 \\
\hline & INFLATION & -2.519894 & 1750.212 & -0.001440 & 0.9989 \\
\hline & FIRM SIZE & -92.28409 & 65.38698 & -1.411353 & 0.1785 \\
\hline
\end{tabular}

According to Table 4, the panel regression model equation generated in the first test which is a model that analyzes the DPR as a whole (combined) with the REM estimation model is:

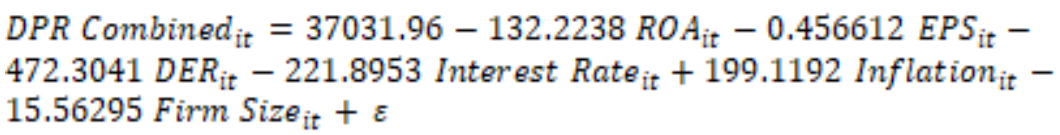

In the first equation, the results of the ROA regression coefficient research are -132.2238 , with a probability value of 0.0309 which is smaller than the $5 \%$ significance level so that it can be concluded that ROA has a significant negative effect on the DPR. The EPS regression coefficient obtained is -0.456612 , with a probability value of 0.4151 which is greater than the $5 \%$ significance level, so it can be concluded that EPS has no significant effect on the DPR. The DER regression coefficient obtained is -472.3041 , with a probability value of 0.6061 which is greater than the $5 \%$ significance level, so it can be concluded that DER has no significant effect on the DPR. The interest rate regression coefficient obtained is -221.8953 , with a probability value of 0.3909 which is greater than the $5 \%$ significance level, so it can be concluded that interest rates have no significant effect on the DPR. The obtained inflation regression coefficient is 199.1192 , with a probability value of 0.8199 which is greater than the $5 \%$ significance level, so it can be concluded that inflation has no significant effect on the DPR. The regression coefficient of the firm size control variable obtained is -15.56295 , with a probability value of 0.0676 which is smaller than the $10 \%$ significance level, so it can be concluded that firm size has a significant negative effect on the DPR.

The panel regression model equation generated in the second test, which is a model that analyzes the DPR with the low dividend grouping using the CEM estimation model, is:

$$
\begin{aligned}
& \text { Low Div }_{\text {it }}=3124.170+31.23386 \text { ROA }_{\text {it }}-0.454823 \text { EPS }_{\text {it }}-164.1023 \text { DER }_{\text {it }}+ \\
& 6.551491 \text { Interest Rate } \\
& \text { it }
\end{aligned}
$$

In the second equation, the results of the ROA regression coefficient research are 31.23386, with a probability value of 0.3283 which is greater than the $5 \%$ significance level so it can be concluded that ROA has no significant effect on the DPR. The EPS regression coefficient obtained is -0.454823 , with a probability value of 0.1164 which is greater than the $5 \%$ significance level, so it can be concluded that EPS has no significant effect on the DPR. The DER regression coefficient obtained is -164.1023 , with a probability value of 0.6476 which is greater than the $5 \%$ significance level, so it can be concluded that DER 
has no significant effect on the DPR. The interest rate regression coefficient obtained is 6.551491, with a probability value of 0.9724 which is greater than the $5 \%$ significance level, so it can be concluded that interest rates do not have a significant effect on the DPR. The inflation regression coefficient obtained is 894.0544, with a probability value of 0.1626 which is greater than the $5 \%$ significance level so that it can be concluded that inflation has no significant effect on the DPR. The regression coefficient of the firm size control variable obtained is -1.226451 , with a probability value of 0.6233 which is greater than the $5 \%$ significance level, so it can be concluded that firm size has no significant effect on the DPR.

The panel regression model equation generated in the third test is a model that analyzes the DPR with the high dividend grouping using the FEM estimation model, is:

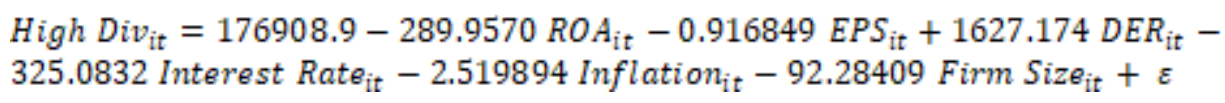

In the third equation, the results of the ROA regression coefficient research are -289.9570 , with a probability value of 0.0067 which is smaller than the $5 \%$ significance level so that it can be concluded that ROA has a significant negative effect on the DPR. The EPS regression coefficient is -0.916849 , with a probability value of 0.3835 which is greater than the $5 \%$ significance level, so it can be concluded that EPS has no significant effect on the DPR. The DER regression coefficient obtained is -1627.174 , with a probability value of 0.5422 which is greater than the $5 \%$ significance level, so it can be concluded that DER has no significant effect on the DPR. The interest rate regression coefficient obtained is -325.0832 , with a probability value of 0.6218 which is greater than the $5 \%$ significance level, so it can be concluded that the interest rate has no significant effect on the DPR. The obtained inflation regression coefficient is 2.519894, with a probability of 0.9989 which is greater than the $5 \%$ significance level, so it can be concluded that inflation has no significant effect on the DPR. The regression coefficient obtained by the control variable firm size is -92.28409 , with a probability value of 0.1785 which is greater than the $5 \%$ significance level, so it can be concluded that firm size has no significant effect on the DPR.

\section{Coefficient of Determination}

Coefficient of determination test is used to explain the ability of the independent variable to explain the dependent variable. Coefficient of determination test results can be seen in Table 5 .

Table 5. Coefficient of Determination Result

\begin{tabular}{lc}
\hline & Adjusted R-Square \\
\hline [1] DPR & 0.045524 \\
[2] Low Dividend & 0.101498 \\
[3] High Dividend & 0.279430 \\
\hline
\end{tabular}

In Table 5, it can be seen that the Adjusted R-Square in the first test, second test, and third tests are 0.045524; 0.101498; and 0.279430, so it is concluded that the ability of the independent variables in the first, second, and third equations in explaining the dependent variable is $4.55 \%, 10.15 \%$, and $27.94 \%$ is explained by other variables outside the study.

\section{Discussion}

The result of this study indicates that in the first and third equations ROA has a significant negative effect on the combined DPR and DPR which are classified as high dividend. In this condition, it means that when the company gets low profitability to fulfill what shareholders want, which leads to the bird in hand theory and maintaining the company's reputation, it will pay large dividends. By maintaining a large dividend distribution, shareholders expect high profitability even though the reality is the opposite. There is conformity in the result of this study with previous researches conducted by (Atmoko et al., 2017; Hasan et al., 2015; Nuringsih, 2005) who stated that ROA has a negative effect on the DPR. Meanwhile, in the second equation ROA does not have a significant effect on the DPR which is classified as low dividend. This means that the higher the profitability of the company, the greater the number of dividends to be distributed, and conversely, companies with low profitability may not necessarily unable to pay dividends to shareholders. There is conformity with the result of this study with previous researches conducted by (Kurniawan et al., 2016; Sumanti \& Mangantar, 2015; Swastyastu et al., 2014) which stated that ROA has no significant effect on the DPR.

The result of this study indicates that the three EPS equations have no significant effect on the combined DPR, DPR which is classified as low dividend and high dividend means that the size of the EPS 
value does not necessarily affect the company's dividend distribution policy. The results contradict the theory which states that there is a positive relationship between EPS and DPR in which the higher the EPS value indicates the greater the profit received resulting in the possibility of increasing the number of dividends distributed to shareholders (Ahmed \& Murtaza, 2015; Ardiyanti, 2014; Yudhanto \& Aisjah, 2011; Zulkifli et al., 2017). This is influenced by the tendency of companies in allocating profits to maintain company liquidity and meet funding needs to run a business and expand it. But, there is conformity with the result of this study with previous researches conducted by (Pamungkas et al., 2017; Purwanti \& Sawitri, 2011) which stated that EPS has no significant effect on the DPR.

The result of this study indicates that the three DER equations have no significant effect on the combined DPR, the DPR which is classified as low dividend and high dividend. This finding does not support the statement that the higher the company's debt, the lower the dividend distributed. The results do not support the theory which states that there is a negative relationship between DER and DPR which states the higher the loan, the more the company prioritizes profit as its obligation to pay the loan rather than dividends resulting in lower dividends distributed to shareholders (Kautsar, 2012; Laim et al., 2015; Mufidah, 2018). This can be caused by the impact of the use of debt in financing on company management. The company will strive to get dividends from their profits rather than use it to finance debt. The result of this study is in accordance with researches conducted by (Kurniawan et al., 2016; Pamungkas et al., 2017; Sumanti \& Mangantar, 2015; Swastyastu et al., 2014) which stated that DER has no significant effect on the DPR.

The result shows that the three interest rate equations do not have a significant effect on the combined DPR, which is classified as low dividend and high dividend. The results contradict the theory which states that there is a positive relationship between interest rate and DPR which states the higher the capital interest rate born by the company, the higher the risk faced by the company causing the higher distribution of dividends due to the pressure of shareholders (Khan et al., 2013; Sasu et al., 2017). Low interest rates do not necessarily increase the company's ability to distribute dividends. This means that the company does not consider interest rates as a reference in distributing dividends to shareholders. The result of this study is in accordance with research conducted by (Ardiyanti, 2014; Ullah et al., 2018) which states that interest rates have no significant negative effect on the DPR. This research is also accordance with research that conducted by (Romus et al., 2020) which stated that interest rates do not have a significant effect on the DPR.

The result shows that the three equations of inflation do not have a significant effect on the DPR, the DPR, which is classified as low dividend and high dividend, which means that the level of inflation does not necessarily affect the number of dividends distributed. The results contradict the theory that there is a negative relationship between inflation and DPR which states that the higher inflation, the higher the company's production costs which results in reduced dividend distribution (Tandelilin, 2010) It is because inflation is not used by the company as a reference in considering the amount of the distributed dividends. The result of this study is conducted with research conducted by (Ardiyanti, 2014) which states that inflation has a negative and insignificant effect on the DPR. This research is also in line with (Elly \& Hellen, 2013) who stated that inflation has no effect on the DPR.

The result shows that in the first equation firm size as a control variable has a significant negative effect on the combined DPR. This means that the larger the size of the company, the lower the amount of dividends distributed because the large amount of assets owned by large companies does not necessarily guarantee that the company will distribute large dividends to shareholders. The results of this study are consistent with research conducted by (Sari et al., 2016) which stated that firm size has a negative effect on the DPR.

Meanwhile, the second and third equations show that firm size as a control variable has no significant effect on the DPR, which is classified as low dividend and high dividend. This means that the firm size does not affect the amount of the dividends distributed. This finding does not support the statement which explained that companies with large sizes are easier to earn profits so that they are able to distribute high dividends. The result of this study is in accordance with researches conducted by (Aziza et al., 2020; Helmina \& Hidayah, 2017; Swastyastu et al., 2014) which stated that firm size has no effect on the DPR.

\section{Conclusion}

Return on assets and firm size have a significant negative effect on the dividend payout ratio. Earnings per share, debt to equity ratio, interest rates and inflation have no significant effect on the dividend payout ratio. Return on assets, earnings per share, debt to equity ratio, interest rates, inflation, and firm size do not have a significant effect on the dividend payout ratio. Return on assets has a 
significant negative effect on the dividend payout ratio. Earnings per share, debt to equity ratio, interest rates, inflation, and firm size have no significant effect on the dividend payout ratio. These findings are expected to be one of the considerations for investors to pay more attention to the return on assets and firm size of the company in determining investments so that the maximum dividend returns can be obtained.

\section{References}

Ahmed, S., \& Murtaza, H. (2015). Critical Analysis of the Factors Affecting the Dividend Payout: Evidence from Pakistan. International Journal of Economics, Finance and Management Sciences, 3(3), 204212. https://doi.org/10.11648/j.ijefm.20150303.17

Al-Malkawi, H.-A. N., Rafferty, M., \& Pillai, R. (2010). Dividend Policy: A Review of Theories and Empirical Evidence. International Bulletin of Business Administration, 9, 171-200. http://www.academia.edu/download/32143154/DividendMalkawi_Rafferty_Pillai_IBBA_9_201 $0 . p d f$.

Amah, N. (2012). Faktor-Faktor Yang Mempengaruhi Dividend Policy Perusahaan Go Public Di Indonesia. ASSETS: Jurnal Akuntansi Dan Pendidikan, 1(1), 45-55. https://doi.org/10.25273/jap.v1i1.525

Ardiyanti, N. R. S. A. (2014). Pengaruh Faktor-Faktor Fundamental dan Teknikal terhadap Dividend Payout Ratio. Jurnal Riset Akuntansi Dan Perpajakan, 2(2), 218-228. https://doi.org/10.35814/jrap.v2i02.113

Atmoko, Y., Defung, F., \& Tricahyadinata, I. (2017). Pengaruh Return On Assets, Debt to Equity Ratio, dan Firm Size Terhadap Dividend Payout Ratio. KINERJA: Jurnal Ekonomi Dan Manajemen, 14(2), 103109. http://dx.doi.org/10.29264/jkin.v14i2.2486

Aziza, D. D. N., Dewi, R. R., \& Fajri, R. N. (2020). Pengaruh Board Independence, Firm Size, Debt To Equity Ratio, Net Profit Margin Terhadap Kebijakan Dividen Pada Perusahaan (Sub Sektor Perusahaan Makanan dan Minuman yang Terdaftar Di BEI 2009 - 2018). Jurnal Riset Akuntansi \& Komputerisasi Akuntansi, 11(1), 117-133. https://doi.org/10.33558/10.33558/jrak.v9i2.1589

Brigham, E. F., \& Houston, J. F. (2011). Dasar-Dasar Manajemen Keuangan (Buku Dua.). Salemba Empat.

Elly, O. D., \& Hellen, K. W. (2013). Relationship between Inflation and Dividend Payout for Companies Listed At the Nairobi Securities Exchange. International Journal of Education and Research, 1(6), 18.

Febriani, A., \& Sari, M. (2019). Pengaruh Firm Size dan Growth Opportunity Terhadap Return on Assets dan Dividend Payout Ratio. Jurnal Ilmiah Magister Manajemen, 2(2), 184-199. https://doi.org/10.30596/maneggio.v2i2.3775

Harianja, H., Lubis, A. F., \& Torong, Z. B. (2013). Analisa Faktor-Faktor Yang Mempengaruhi Kebijakan Dividen Dengan Cash ratio Sebagai Variabel Moderating Pada Perusahaan Barang Konsumsi Yang Terdaftar Di Bursa Efek Indonesia. Jurnal Telaah \& Riset Akuntansi, 6(2), 109-121. http://www.jurnal.unsyiah.ac.id/TRA/article/view/1323

Hasan, M., Ahmad, M. I., \& Rafiq, M. Y. (2015). Dividend Payout Ratio and Firm's Profitability. Evidence from Pakistan. Theoretical Economics Letters, 5(June), 441-445. https://doi.org/10.4236/tel.2015.53051

Helmina, M. R. A., \& Hidayah, R. (2017). Pengaruh Institusional Ownership, Collaterizable Assets, Debt to Total Assets, Firm Size Terhadap Dividend Payout Ratio. Jurnal Ilmiah Ekonomi Bisnis, 3(1), 24-32. https://doi.org/10.35972/jieb.v3i1.49

Kautsar, A. (2012). Pengaruh Return On Equity (ROE), Debt to Equity Ratio (DER), Investment Opportunity Set (IOS), dan Inflasi Terhadap Dividend Payout Ratio (DPR). Jurnal Bisnis Dan Manajemen, 4(2), 154-166. https://doi.org/10.26740/bisma.v4n2.p154-166

Keown, A. J., Martin, J. H., Petty, J. W., \& Scott, D. F. (2003). Financial Management: Principles and Applications 10th ed. Prentice Hall.

Khan, M. I., Meher, M. A. K., \& Kashif, S. M. (2013). Impact of Inflation on Dividend Policy: Synchronization of Capital Gain and Interest Rate. Pensee Journal, 75(11), 384-393. https://mpra.ub.unimuenchen.de/51593/

Kurniawan, E. R., Arifati, R., \& Andini, R. (2016). Pengaruh Cash Position, Debt Equity Ratio, Return On Asset, Current Ratio, Firm Size, Price Earnings Ratio, dan Total Assets Turn Over Terhadap 
Dividend Payout Ratio Pada Perusahaan Manufaktur Periode 2007-2014. Journal Of Accounting, 2(2), 1-13. http://jurnal.unpand.ac.id/index.php/AKS/article/view/463

Laim, W., Nangoy, S. C., \& Murni, S. (2015). Analisis Faktor-Faktor yang Mempengaruhi Dividend Payout Ratio Pada Perusahaan Yang Terdaftar di Indeks LQ-45 Bursa Efek Indonesia. Jurnal EMBA, 3(1), 1129-1140. https://doi.org/10.35794/emba.v3i1.7927

Lucyanda, J., \& Lilyana. (2012). Pengaruh Free Cash Flow dan Struktur Kepemilikan Terhadap Dividend Payout Ratio. Jurnal Dinamika Akuntansi, 4(2), 129-138. https://doi.org/10.15294/jda.v4i2.2171

Mufidah. (2018). Pengaruh Asset Growth, Sales Growth, Net Profit Margin, Current Ratio dan Debt To Equity Ratio terhadap Dividend Payout Ratio pada Perusahaan yang Termasuk dalam Indeks Lq 45 Tahun 2013 - 2016. Jurnal Manajemen Dan Sains (JMAS), 3(1), 12-25. https://doi.org/10.33087/jmas.v3i1.39

Nuringsih, K. (2005). Analisis Pengaruh Kepemilikan Manajerial, Kebijakan Utang, ROA dan Ukuran Perusahaan Terhadap Kebijakan Dividen: Studi 1995-1996. Jurnal Akuntansi Dan Keuangan Indonesia, 2(2), 103-123. http://dx.doi.org/10.33087/jmas.v3i1.39

Odawo, C., \& Ntoiti, J. (2015). Determinants Of Dividend Payout Public Policy In Public LTD Banks In Kenya: A Case Study Of CFC Stanbic Bank. The Strategic Journal of Business and Change Management, 2(2), 182-191. http://citeseerx.ist.psu.edu/viewdoc/download?doi=10.1.1.931.4382\&rep=rep1\&type=pdf

Okpara, G. C. (2010). Asymmetric Information and Dividend Policy in Emerging Markets: Empirical Evidence from Nigeria. International Journal of Economics and Finance, 2(4), 212-220. https://doi.org/10.5539/ijef.v2n4p212

Pamungkas, N., Rusherlistyani, \& Janah, I. (2017). Pengaruh Return On Equity, Debt to Equity Ratio, Current Ratio, Earning Per Share dan Investment Opportunity Set Terhadap Kebijakan Dividen. Jurnal Analisa Akuntansi Perpajakan, 1(1), 34-41.

Purwanti, D., \& Sawitri, P. (2011). Dampak Rasio Keuangan Terhadap Kebijakan Dividen. Jurnal Bisnis Dan Manajemen, 3(2), 125-134. https://doi.org/10.26740/bisma.v3n2.p125-134

Rahayuningtyas, S., Suhadak, \& Handayani, S. R. (2012). Pengaruh Rasio-Rasio Keuangan Terhadap Dividend Payout Ratio (DPR) (studi Pada Perusahaan Yang Listing Di BEI Tahun 2009-2011). Jurnal Administrasi Bisnis, $7(2), \quad 1-9$. http://administrasibisnis.studentjournal.ub.ac.id/index.php/jab/article/view/326

Romus, M., Anita, R., Abdillah, M. R., \& Zakaria, N. B. (2020). Selected Firms Environmental Variables: Macroeconomic Variables, Performance and Dividend Policy Analysis. IOP Conf. Series: Earth and Environmental Science, 469(012047), 1-6. https://doi.org/10.1088/1755-1315/469/1/012047

Saeed, D. R., Riaz, A., Lodhi, R. N., Munir, H. M., \& Iqbal, A. (2014). Determinants of Dividend Payouts in Financial Sector of Pakistan. Journal of Basic and Applied Scientific Research, 4(2), 33-42. http://www.academia.edu/download/34182343/financial_sector.pdf.

Sari, M. R., Oemar, A., \& Andini, R. (2016). Pengaruh Pertumbuhan Perusahaan, Ukuran Perusahaan, Earning Per Share, Current Ratio, Return on Equity Ratio dan Debt Equity Ratio Terhadap Kebijakan Dividend. Journal of Accounting, 2(2), 1-13. http://jurnal.unpand.ac.id/index.php/AKS/article/view/455

Sasu, D. O., Abor, J. Y., \& Osei, A. K. (2017). Dividend Policy and Shareholders' Value: Evidence from Listed Companies in Ghana. African Development Review, 29(2), 293-304. https://doi.org/10.1111/14678268.12257

Silaban, C. N., \& Pengestuti, I. R. D. (2017). Analisis Faktor-Faktor yang Mempengaruhi Kebijakan Dividen dengan Firm Size sebagai Variabel Kontrol (Studi pada Perusahaan Manufaktur yang Terdaftar di BEI Tahun 2011- 2015). Diponegoro Journal of Management, 6(3), 1-15. https://ejournal3.undip.ac.id/index.php/djom/article/view/17320

Sumanti, J. C., \& Mangantar, M. (2015). Analisis Kepemilikan Manajerial, Kebijakan Hutang dan Profitabilitas Terhadap Kebijakan Dividen dan Nilai Perusahaan Pada Perusahaan Manufaktur yang Terdaftar di BEI. Jurnal EMBA, 3(1), 1141-1151. https://doi.org/10.35794/emba.v3i1.7928

Sunarya, D. H. (2013). Pengaruh Kebijakan Utang, Profitabilitas Dan Likuiditas Terhadap Kebijakan Dividen Dengan Size Sebagai Variabel Moderasi Pada Sektor Manufaktur Periode 2008-2011. Jurnal Ilmiah Mahasiswa Universitas Surabaya, 2(1), 1-19. http://journal.ubaya.ac.id/index.php/jimus/article/view/381 
Swastyastu, M. W., Yuniarta, G. A., \& Atmadja, A. T. (2014). Analisis Faktor-Faktor yang Mempengaruhi Kebijakan Dividend Payout Ratio yang Terdaftar di Bursa EFEK Indonesia (BEI). Jurnal Ilmiah Mahasiswa Akuntansi, 2(1), 1-12. http://dx.doi.org/10.23887/jimat.v2i1.3443

Tandelilin, E. (2010). Portofolio dan Investasi: Teori dan Aplikasi (Edisi Pert). Kanisius.

Ullah, A., Anjum, N., Ali, M. A., \& Khan, F. (2018). Impact of Macroeconomic Variables on the dividend payout ratio: Evidence from the Textile Sector listed on the Pakistan Stock Market. Research Article University of Swabi Journal (USJ), $2(1), \quad$ 1-7. http://www.academia.edu/download/57830910/Impact_of_Macroeconomic_Variables_on_the_divi dend_payout_ratioEvidence_from_the_Textile.pdf.

Yudea. (2017). Pengaruh Current Ratio, Debt to Equity Ratio, Return On Assets Terhadap Dividend Payout Ratio (Studi Kasus Perusahaan Manufaktur Periode 2012-2016). Jurnal Ekonomi Dan Bisnis, 20(01), 35-40. https://doi.org/10.31941/jebi.v20i1.740

Yudhanto, S., \& Dr. Siti Aisjah, SE, M. (2011). Pengaruh Net Profit Margin, Return On Asset, Return On Equity, Earnings Per Share Terhadap Kebijakan Dividen (Studi pada Perusahaan Manufaktur yang Terdaftar Di Bursa Efek Indonesia). Jurnal Ilmiah Mahasiswa FEB, 1(2), 1-14. https://jimfeb.ub.ac.id/index.php/jimfeb/article/view/509

Zulkifli, Endri, \& Kurniasih, A. (2017). Determinan Internal Dividend Payout Ratio Perusahaan Farmasi Terdaftar Di Bursa Efek Indonesia. Jurnal Keuangan Dan Perbankan, 21(040), 238-252. 